\title{
KODE ETIK WISATAWAN DALAM MENUNJANG KELESTARIAN GUNUNG API PURBA NGLANGGERAN
}

\author{
Eryd Saputra \\ Program Studi Manajemen Kuliner Politeknik Pariwisata Batam \\ Jl. Gajah Mada, The Vitka City Complex, Tiban, Kota Batam, \\ Kepulauan Riau, Indonesia
}

Korespodensi dengan Penulis:

Eryd Saputra: Telp: 081364644385

Email: saputra.eryd@gmail.com

\begin{abstract}
Nglanggeran ancient volcano is the main tourist attraction in Gunungkidul regency in which the number of the visitor is quite high. In order to maintain the ancient volcano preservation on the future, guidance is needed to organize the manner of the tourist. Tourist code of conduct is one of the way which may be able to minimize social effects, culture, and tourist attraction environments. The purpose of this research was to analyze the strategy, which have been done by the eco-tourism administrator area of Nglanggeran ancient volcano in applying the tourist codes of conduct towards tourist behavior. This research was conducted through qualitative descriptive method, along with participant observation, interview, and documentation as data for instruments collection. The result of this research shows that the ecotourism administrator area has already applied the tourism codes of conduct to the tourist. It impacts on the changes of the tourist attitude to pay more attention to the environment.
\end{abstract}

Keywords: Tourist Code of Conduct; Environmental Sustainability;

Perkembangan industri pariwisata sangat cepat, baik di negara lain maupun Indonesia. Sebagai sebuah industri pariwisata memberikan dampak yang positif, bagi pemerintah, masyarakat, dan sektor swasta. Hal ini tercantum pada Undang-Undang RI Nomor 10 Th. 2009 tentang Kepariwisataan Pasal 4 bahwa pariwisata bertujuan untuk meningkatkan pertumbuhan ekonomi; meningkatkan kesejahteraan rakyat; menghapus kemiskinan; mengatasi pengangguran; melestarikan alam, lingkungan, sumber daya; dan memajukan kebudayaan. Namun pariwisata juga tidak selamanya memberikan dampak yang positif, apabila tidak dikelola dengan baik dan benar.

Perubahan pola pembangunan pariwisata yang sebelumnya hanya 
mengedepankan aspek ekonomi dan menilai bahwa jumlah kunjungan menjadi tolak ukur keberhasilan suatu destinasi atau yang sering disebut dengan pariwisata massal (mass tourism). Pariwisata massal ini banyak menimbulkan dampak yang negatif seperti kerusakan lingkungan, perubahan sosial budaya pada suatu lingkungan yang menjadi destinasi wisata. Intinya adalah bahwa pariwisata konvensional cenderung mengancam kelestarian sumberdaya pariwisata itu sendiri (Damanik \& Weber, 2006).

Daerah Istimewa Yogyakarta merupakan salah satu daerah tujuan wisata unggulan di Indonesia, baik bagi wisatawan nusantara ataupun wisatawan mancanegara. Beragamnya daya tarik wisata yang dapat dinikmati oleh wisatawan, baik yang berbasis budaya, alam, maupun buatan manusia. Pariwisata menjadi salah satu fokus utama pemerintah Daerah Istimewa Yogyakarta dalam meningkatkan pendapatan asli daerah serta meningkatkan kesejahteraan masyarakatnya.

Gunungkidul merupakan salah satu kabupaten yang ada di Daerah
Istimewa Yogyakarta. Kabupaten Gunungkidul ini mempunyai banyak daya tarik wisata, salah satunya adalah kawasan ekowisata gunung api purba nglanggeran. Pada kawasan ekowisata ini terdapat gunung nglanggeran atau kini lebih dikenal dengan sebutan gunung api purba. Secara fisiografi gunung api purba nglanggeran terletak di zona pegunungan selatan Jawa TengahJawa Timur (Van Bemmelen 1949) atau tepatnya di sub zona pegunungan baturagung (baturagung range) dengan ketinggian 700 meter dari permukaan laut dan kemiringan lerengnya curamterjal $(>45 \%)$.

\section{Gunung}

nglanggeran

berdasarkan sejarah geologinya merupakan gunung api purba yang berumur tersier (Oligo- Miosen) atau 0,6 - 70 juta tahun yang lalu. Material batuan penyusun gunung nglanggeran merupakan endapan vulkanik tua berjenis andesit (Old Andesite Formation). Jenis batuan yang ditemukan di gunung nglanggeran antara lain breksi andesit, tufa dan lava bantal. Singkapan batuan vulkanik klastik yang ditemukan di gunung nglanggeran penampakannya 
sangat ideal dan oleh karena itu maka, satuan batuan yang ditemukan di gunung tersebut menjadi lokasi tipe (type location) dan diberi nama formasi geologi nglanggeran.

Gunung api purba nglanggeran menjadi magnet yang kuat dalam meningkatkan jumlah kunjungan wisatawan ke Kabupaten Gunungkidul. Jumlah kunjungan wisatawan yang banyak dapat menimbulkan dampak negatif bagi lingkungan gunung api purba, hal ini disebabkan oleh kebiasaan atau perilaku wisatawan yang berbedabeda.

Pengarah tentang perilaku yang sesuai dengan yang diinginkan menjadi penting untuk dibentuk oleh pengelola kawasan ekowisata gunung api purba nglanggeran. Menurut Song (2000) kode etik (code of conduct) merupakan seperangkat aturan perilaku yang dirumuskan baik sebagai kesepakatan, norma sosial, atau aturan hukum yang dapat mendapat sanksi oleh penegak otoritas.

Pembuatan kode etik (code of conduct) bertujuan untuk meningkatkan kesadaran wisatawan, mengedukasi wisatawan, mencegah konflik antar stakeholder terutama antara masyarakat lokal sebagai tuan rumah dan wisatawan, memperbaiki perilaku wisatawan dan sebagai salah satu strategi manajemen untuk memastikan konservasi sumber daya yang ada (Mason, 1994 dalam Mason \& Mowforth, 1995).

Kode etik wisatawan sangat penting dalam menjaga kelestarian lingkungan. Kelestarian berarti suatu kapasitas untuk memelihara dan menjaga beberapa entitas, manfaat ataupun proses-proses dalam lintasan waktu tertentu sehingga secara teori kelestarian adalah suatu upaya untuk memprioritaskan dan mengintegrasikan tanggung jawab sosial kedalam permasalahan lingkungan dan budaya Jenkins (2008) dalam (Sasongko, 2014).

Permasalahan yang sering terjadi di daya tarik wisata adalah wisatawan sering melakukan tindakan yang tidak mencerminkan kecintaanya pada lingkungan, contohnya membuang sampah sembarangan dan vandalisme. Perilaku wisatawan tersebut dapat diminimalisir dengan menerapkan kode etik wisatawan. 
Penelitian ini bertujuan untuk menganalisis strategi yang dilakukan pengelola kawasan ekowisata gunung api purba nglanggeran dalam menerapkan kode etik wisatawan dan melihat bagaimana pengaruh dari penerapan kode etik terhadap perilaku wisatawan.

\section{METODE}

Jenis penelitian yang digunakan adalah peneltian kualitatif. Berdasarkan tujuan penelitian, analisis data yang digunakan untuk menganalisa tujuan penelitian adalah metode deskriptif. Metode deskriptif, adalah mentransformasi data mentah kedalam bentuk yang mudah dimengerti dan ditafsirkan, termasuk menyusun, dan menyajikan supaya menjadi suatu informasi yang akurat (Kusmayadi dan Sugiarto, 2000). Lokasi penelitian ini di Desa Ngalanggeran Kecamatan Patuk, Kabupaten Gunungkidul, Daerah Istimewa Yogyakarta.

Sumber data primer pada penelitian ini adalah pengelola dan pemandu wisata, sedangkan data sekunder diperoleh dari artikel, jurnal penelitian, internet dan sumber data lain yang berhubungan dengan penelitian ini. Teknik pengumpulan data pada penelitian ini melalui wawancara, observasi partisifatif dan dokumentasi.

Wawancara merupakan proses interaksi dan komunikasi antara pengumpul data dengan responden dengan cara bertanya langsung kepada responden dan jawabannya dicatat atau direkam dengan alat perekam (Kusmayadi dan Sugiarto, 2000). Wawancara yang yang dilakukan dengan pengelola menggunakan teknik wawancara tertutup, sedangkan wawancara terbuka dilakukan dengan pemandu wisata.

Observasi partisipatif merupakan observasi yang melibatkan peneliti atau merasakan langsung keadaan yang dialami oleh sumber data di lokasi wisata. Jadi data yang diperoleh akan lebih lengkap, tajam, dan sampai mengetahui makna dari setiap perilaku yang nampak (Sugiyono, 2013).

\section{HASIL DAN PEMBAHASAN}

\section{A. Hasil Penelitian}

Kode etik wisatawan merupakan 
salah satu faktor kunci dalam menjaga kelestarian lingkungan. Kode etik yang dibuat untuk pengunjung ini, berfungsi untuk mempengaruhi dan mengarahkan perilaku pengunjung, isi dari kode etik biasanya berhubungan dengan hal yang dilarang dan sesuatu yang dianjurkan untuk keamanan pengunjung dalam melakukan aktifitas wisatanya.

Pengelola kawasan ekowisata gunung api purba telah menerapkan kode etik terhadap wisatawan. Berdasarkan hasil wawancara dengan pengelola, terdapat dua strategi kode etik yang digunakan dalam mempengaruhi tingkah laku wisatawan, yaitu kode etik tertulis dan kode etik lisan.

Pertama, kode etik tertulis yang telah diterapkan oleh pengelola, berisi tentang himbauan yang harus diperhatikan wisatawan dalam melakukan wisata di gunung api purba, antara lain:

1. Mohon tidak mengambil sesuatu yang ada dikawasan ini.

2. Mohon tidak melakukan coretan dan pahatan pada batu yang ada dikawasan ini.
3. Mohon tidak membuang sampah di kawasan ini.

Himbauan ini bertujuan untuk mengingatkan wisatawan agar berperilaku baik saat berkunjung. Pada himbauan ini tidak terdapat sanksi yang diberikan apabila wiastawan melakukan pelanggaran.

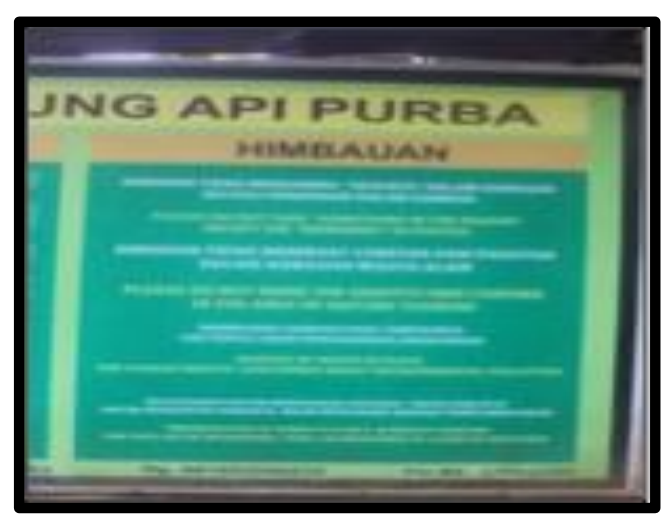

Gambar 1. Papan Himbauan Kode Etik di Gunung Api Purba

Sumber: Hasil Observasi (2016)

Selain kode etik tertulis diatas, ada juga himbauan tentang denda yang dikenakan pada pengunjung apabila melakukan pelanggaran. Denda berupa pembayaran sejumlah uang yaitu berkisar antara Rp. 1.000.000 hingga Rp. $\quad 5.000 .000$ bergantung dari jenis pelanggarannya. Penerapan denda tersebut dapat mempengaruhi tingkah laku wisatawan saat berkunjung ke gunung api purba. 


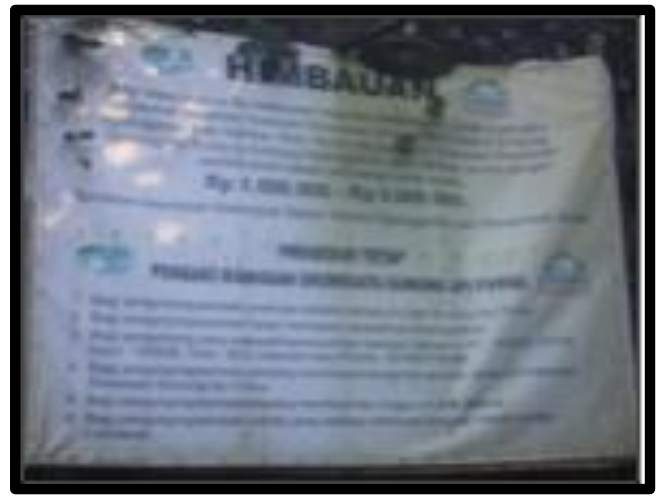

Gambar 2. Informasi bagi Pelanggar Kode Etik di Gunung Api Purba

Sumber: Hasil Observasi (2016)

Kode etik tertulis harus didukung oleh letak yang strategis agar lebih efektif pengaruhnya. Berdasarkan data observasi dan wawancara dengan pemandu wisata letak kode etik tertulis telah ditempatkan pada lokasi yang mudah dilihat oleh wisatawan.

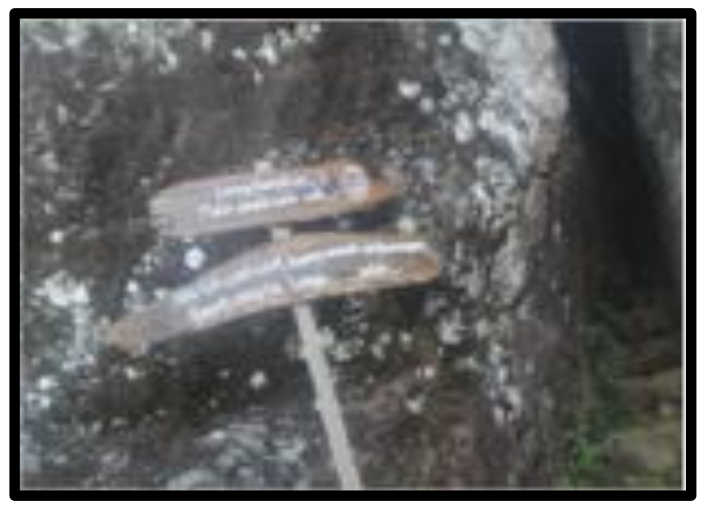

Gambar 3. Lokasi Penempatan Kode Etik Wisatawan di Gunung Api Purba

Sumber: Hasil Observasi (2016)

Kedua, Kode etik lisan merupakan himbauan yang berasal dari kearifan lokal. Himbuan ini berupa cerita yang disampaikan oleh pemandu wisata pada pengunjung. Peran pemandu wisata menjadi penting dalam kode etik ini, sebab keefektifannya tergantung pada keahlian pemandu wisata dalam menyampaikannya. Cerita yang disampaikan pemandu mengarah pada sesuatu yang sakral (tempat yang dihuni oleh leluhur dahulu), jadi wisatawan dianjurkan agar menjaga tingkah lakunya pada saat kunjungan.

Berdasarkan wawancara dengan pengelola wisata, diperoleh hasil yang berbeda dari penerapan kedua strategi kode etik tersebut. Kode etik yang paling efektif adalah kode etik yang berdasarkan pada kearifan lokal. Hal ini disebabkan oleh budaya masyarakat yang masih percaya dengan sesuatu bersifat animisme atau metafisika. Pendapat ini juga diperkuat oleh pemandu wisata, bahwa cerita berdasarkan kearifan lokal lebih memberikan dampak yang besar terhadap perilaku wisatawan.

Secara keseluruhan kode etik wisatawan yang dilakukan oleh pengelola telah berpengaruh terhadap perilaku wisatawan. Pendapat ini berdasarkan hasil wawancara dengan 
pemandu wisata gunung api purba. Pemandu wisata telah jarang melihat wisatawan melakukan hal yang merusak seperti membuang sampah di sembarang tempat dan jumlah sampah yang dikumpulkan oleh petugas kebersihan telah jauh berkurang dari pada tahun-tahun sebelumnya. Selain jumlah sampah yang berkurang vandalisme oleh wisatawan juga telah berkurang. Perubahan perilaku wisatawan tersebut memberikan dampak positif terhadap kelestarian lingkungan gunung api purba.

\section{B. Pembahasan}

Pengelola kawasan ekowisata gunung api purba nglanggeran menerapkan 2 (dua) strategi dalam menyampaikan kode etik wisatawan, yaitu kode etik tertulis dan kode etik lisan.

\section{Kode etik tertulis}

Kode etik tertulis berisikan norma-norma yang harus dihindari atau dilarang untuk dilakukan oleh wisatawan yang berkunjung. Hal ini bertujuan untuk mengarahkan perilaku wisatawan sesuai dengan kehendak pengelola kawasan.
Pemahaman code of conduct dalam konteks pariwisata, merupakan kode yang yang digunakan sebagai panduan umum untuk berperilaku Weaver (2001) dalam Akhom (2011).

Pada kode etik tertulis terdapat juga sanksi yang dikenakan apabila terjadi pelanggaran kode etik tersebut. Hal ini sejalan dengan pendapat Song (2000) dimana kode etik (code of conduct) merupakan seperangkat aturan perilaku yang dirumuskan baik sebagai kesepakatan, norma sosial, atau aturan hukum berupa sanksi oleh penegak otoritas. Dalam hal ini pengelola telah melakukan konsep kode etik wisatawan dengan tepat, sebab ada sanksi yang dikenakan apabila terjadi pelanggaran kode etik contoh sanksinya berupa denda dan sanksi sosial.

Penerapan strategi kode etik tertulis harus didukung dengan tata bahasa yang baik dan letak yang tepat. Dalam hal ini pengelola kawasan ekowisata gunung api purba nglanggeran telah memperhatikan bagian tersebut.

Gaya bahasa pada kode etik tulisan di gunung api purba telah 
tepat, hal dilihat kata mohon yang diletakkan diawal kalimat.

a. Mohon tidak mengambil sesuatu yang ada dikawasan ini.

b. Mohon tidak melakukan coretan dan pahatan pada batu yang ada dikawasan ini.

c. Mohon tidak membuang sampah di kawasan ini.

Hal ini sejalan dengan Konsep WWF (2001) dalam Cole, (2006), code of conduct sebaiknya dinyatakan secara positif, berorientasi tindakan dan menghindari bahasa larangan. Kata mohon memberikan makna kuat pada kalimat kode etik yang buat oleh pengelola kawasan ekowisata gunung api purba nglanggeran, menurut Kamus Besar Bahasa Indonesia (KBBI) mohon mempunyai makna meminta dengan hormat.

Tata letak kode etik tertulis juga berpengaruh terhadap keefektifannya. Kode etik tertulis ditempatkan oleh pengelola pada tempat yang mudah dilihat, seperti di tepi jalan setapak, di tempat pemberhentian (gardu pandang), dan lokasi yang memungkinkan terjadinya pelanggaran.

\section{Kode etik lisan}

Kode etik lisan merupakan strategi lain yang digunakan pengelola dalam mengarahkan perilaku wisatawan. Kode etik ini disampaikan oleh pemandu wisata pada wisatawan saat berkunjung. Kode etik tersebut berdasarkan kearifan lokal yang ada di gunung api purba. Kearifan lokal ini berupa cerita tentang kesakralan gunung api purba.

Kode etik lisan ini tidak mempunyai aturan-aturan tertentu dalam penerapannya, yang terpenting adalah pengemasan cerita yang baik dan mudah diinterpretasikan oleh wisatawan. Keberhasilan kode etik lisan ini tergantung pada keahlian dari pemandu wisata tersebut.

Kode etik lisan ini mempunyai kelemahan, sebab hanya dapat diterapkan apabila wisatawan mengunakan jasa pemandu. Hal yang dapat dilakukan untuk memaksimalkan kode etik ini adalah membuat aturan yang mewajibkan penggunaan jasa pemandu wisata, dengan jumlah tertentu dalam satu grup wisatawan. Namun kalau dibandingkan dengan kode etik tulisan kode etik lisan memberikan 
pengaruh lebih besar terhadap perubahan perilaku wisatawan.

Perubahan perilaku wisatawan yang terjadi di gunung api purba merupakan salah satu dampak dari penerapan kode etik wisatawan yang tepat. Perubahan perilaku tersebut akan memberikan kontribusi yang positif terhadap keberlangsungan gunung api purba dimasa yang akan datang, baik dari segi lingkungannya ataupun budaya yang ada disekitar kawasan gunung tersebut.

\section{KESIMPULAN}

Berdasarkan hasil penelitian dan pembahasan diatas, dapat disimpulkan bahwa:

1. Pengelola kawasan ekowisata gunung api purba nglanggeran telah menerapkan kode etik wisatawan. Terdapat dua strategi yang dilakukan oleh pengelola, yaitu kode etik tertulis dan kode etik lisan.

2. Penerapan kode etik tertulis yang dilakukan oleh pengelola kawasan ekowisata gunung api purba nglanggeran telah tepat, baik dari penerapan sanksi apabila terjadi pelanggaran, tata bahasa yang digunakan, dan tata letak dari kode etik tersebut.

3. Kode etik lisan yang diterapkan oleh pengelola kawasan ekowisata gunung api purba nglanggeran berupa cerita yang berdasarkan kearifan lokal setempat. Kode etik ini lebih efektif dari pada kode etik tertulis, hal ini disebabkan masih kuatnya kepercayaan masyarakat terhadap sesuatu yang dianggap sakral.

4. Kode etik wisatawan yang diterapkan oleh pengelola kawasan ekowisata gunung api purba nglanggeran menjadi salah satu faktor pendukung terhadap perubahan perilaku wisatawan yang berkunjung. Perubahan perilaku wisatwan akan berdampak pada kelesarian lingkungan gunung api purba.

\section{DAFTAR PUSTAKA}

Cole, Stroma. 2007. Implementing and Evaluating a Code Of Conduct For Visitor. Jurnal Tourism Management. No 28 : 443-451

Damanik, J, \& Weber, H. J. 2006Perencanaan Ekowisata dari Teori ke Aplikasi. Yogyakarta: Penerbit Andi. 
Kumayadi dan Sugiarto, Endar. 2000. Metodologi Penelitian dalam Bidang Kepariwisataan. Jakarta: Gramedia Pustaka

Manson, Peter \& Mowforh, Martin. 1995. Code Of Conduct in Tourism. University Of Plymouth

Sasongko, Himawan. 2014. Budaya Klangenan, Pola Konsumsi dan Hubungannya dengan Kelestarian Jenis Satwa Burung di Wilayah Semarang dan Solo Provinsi Jawa Tengah. (Tesis) Universitas Gadjah Mada

Sugiyono. 2013. Memahami Penelitian Kuantitatif Kualitatif dan RED. Bandung: CV. Alfabeta

Song, Yann - Huei. (2000). Codes Of In The South China Sea And Taiwan's Stan., Journal Marine Policy. No 24 hal 449-459.

Undang - Undang RI No 10 Tahun 2009 Tentang Kepariwisataan 